\title{
Mn-Co spinel protective-conductive coating on AL453 ferritic stainless steel for IT-SOFC interconnect applications
}

\author{
Andrzej Kruk • Miroslaw Stygar • Tomasz Brylewski
}

Received: 12 June 2012 /Revised: 9 November 2012 / Accepted: 12 November 2012 / Published online: 30 November 2012

(C) The Author(s) 2012. This article is published with open access at SpringerLink.com

\begin{abstract}
This paper presents research on the synthesis and properties of the $\mathrm{Mn}_{1.5} \mathrm{Co}_{1.5} \mathrm{O}_{4}$ (MC) spinel powder, as well as its application for the preparation of a MC thick film on the AL453 steel to be used for metallic interconnect material in IT-SOFCs. In order to prepare the MC micropowder with excellent homogeneity of the chemical and phase compositions, EDTA gel processes were utilized. In order to improve the contact electrical resistance between an AL453 steel interconnect and the $\mathrm{La}_{0.8} \mathrm{Sr}_{0.2} \mathrm{FeO}_{3}$ (LSF) cathode and protect the cathode from $\mathrm{Cr}$ poisoning, the surface of the AL453 steel was coated with a protective manganese cobaltite spinel matrix using screen printing in combination with an appropriate heat treatment. The oxidation of the AL453/MC composite layer carried out in the air- $\mathrm{H}_{2} \mathrm{O}$ gas mixture at $1,073 \mathrm{~K}$ for $55 \mathrm{~h}$ showed that the spinel coating may serve as an effective barrier against outward $\mathrm{Cr}$ diffusion from the AL453 steel and, therefore, significantly inhibit the formation of volatile $\mathrm{Cr}$ vapors from the chromia scale. The contact ASR study of the interconnect-cathode interface in the AL453/MC/LSCM/LSF/LSCM/MC/AL453 system carried out in the range of $723-1,073 \mathrm{~K}$ in air showed a very large drop in ASR compared to the resistance of the AL453/LSCM/LSF/LSCM/AL453 system without the spinel coating.
\end{abstract}

Keywords Solid oxide fuel cell $\cdot$ Metallic interconnects . Spinel-based coatings $\cdot$ Ferritic stainless steel $\cdot$ Oxidation

A. Kruk $\cdot$ M. Stygar $\cdot$ T. Brylewski $(\bowtie)$

Faculty of Materials Science and Ceramics,

AGH University of Science and Technology, Al. Mickiewicza 30,

30-059 Krakow, Poland

e-mail: brylew@agh.edu.pl
Nomenclature

IT-SOFC Intermediate-temperature solid oxide fuel cell

MC $\quad \mathrm{Mn}_{1.5} \mathrm{Co}_{1.5} \mathrm{O}_{4}$ spinel coating material

AL453 Commercial ferritic steel from Allegheny

Ludlum

EDTA Ethylene-diamine-tetra-acetic acid

LSF $\quad \mathrm{La}_{0.8} \mathrm{Sr}_{0.2} \mathrm{FeO}_{3}$ cathode material

LSCM $\quad \mathrm{La}_{0.8} \mathrm{Sr}_{0.2} \mathrm{Co}_{0.5} \mathrm{Mn}_{0.5} \mathrm{O}_{3}$ conductive material

ASR Area-specific resistance

\section{Introduction}

Intermediate-temperature solid oxide fuel cells (IT-SOFCs) have attracted significant attention due to its potential for highly efficient yet environmentally friendly power generation. However, the main obstacle on the way to the commercialization of the IT-SOFC is the high cost of the stack and its durability related to the long-term stability of stack/ cell components, such as interconnects [1,2]. Bipolar interconnects, the role of which is to connect a large number of single cell elements into a planar-type IT-SOFC stack, are currently developed from high-chromia ferritic steels, such as AL453 [3-6]. The following factors provide arguments in favor of selecting this type of steel: a thermal expansion coefficient closely matching that of the YSZ solid electrolyte, high resistance against high-temperature corrosion, and, furthermore, its chemical stability with respect to the glass sealant used for the construction of the cell stack [5, 7]. Since the AL453 steel is exposed to both air and a reducing $\left(\mathrm{H}_{2}-\mathrm{H}_{2} \mathrm{O}\right)$ atmosphere at the predicted IT-SOFC operation temperature of about $1,073 \mathrm{~K}$, surface modification is required in order to improve the electrical conductivity of the chromia scale or the chromia-rich sublayer [5]. The second 
issue encountered with chromia is their potential transformation into volatile chromium species such as $\mathrm{CrO}_{2}(\mathrm{OH})_{2}$, leading to the loss of their protective properties and the poisoning of the cathode material, and the subsequent degradation in the electrochemical performance of the cell, irrespective of the type of steel used for the construction of SOFC steel interconnects $[8,9]$. One way to effectively reduce such adverse effects is to deposit active protective and conductive coatings of several conducting perovskite [10-12] or spinel [13-16] layers on the surface of ferritic steels. However, for the coating to be able to act as a barrier against chromium diffusion from the steel and against the formation of volatile $\mathrm{Cr}(\mathrm{VI})$ compounds, the inward diffusion coefficient of oxygen ions must be greater than the outward diffusion coefficient of chromium ions [17]. In such circumstances, the diffusion of $\mathrm{O}^{2-}$ throughout the microscopically dense layer is the factor responsible for the growth of the chromia layer on the steel surface and/or intermediate reaction layers formed between the ceramic coating and the steel substrate [17]. Otherwise, if $D\left(\mathrm{Cr}^{3+}\right)>>D\left(\mathrm{O}^{2-}\right)$, the afore-mentioned chromia layer and/or intermediate reaction layers generated under these conditions at the coating/air interface may contribute to the contamination of the cell's electrode spaces, especially the cathode one [17].

Due to its suitable chemical stability, a thermal expansion coefficient compatible with that of the AL453 steel $\left(\Delta T_{\mathrm{MC}}=\right.$ $\left.11.5 \times 10^{-6}\left[\mathrm{~K}^{-1}\right], \Delta T_{\mathrm{AL} 453}=11 \times 10^{-6}\left[\mathrm{~K}^{-1}\right]\right)$, and high electronic conductivity (low $\mathrm{O}^{2-}$ and $\mathrm{Cr}^{3+}$ ionic content), the $\mathrm{Mn}_{1.5} \mathrm{Co}_{1.5} \mathrm{O}_{4}$ manganese cobaltite spinel, which belongs to the family $\mathrm{Co}_{3-x} \mathrm{Mn}_{x} \mathrm{O}_{4}$ (with $0 \leq x \leq 3$ ), is currently being investigated as a potential coating material for steel interconnects $[13,14,18,19]$. One of the simpler methods that may be used to fabricate thick films composed of this spinel is the cost-effective screen printing technique followed by appropriate heat treatment $[20,21]$. Nevertheless, to obtain a highly dense coating that adheres well to the substrate, it is recommended to use microparticle powders with desirable narrow distribution, i.e., a single modalsize particle distribution with very small amounts of agglomerates. In this respect, ethylenediaminetetraacetic acid (EDTA) gel processes used for the preparation of $\mathrm{Mn}_{1.5} \mathrm{Co}_{1.5} \mathrm{O}_{4}$ powder are of particular interest.

In this paper, we present the detailed preparation of a dense $\mathrm{Mn}_{1.5} \mathrm{Co}_{1.5} \mathrm{O}_{4}$ thick film deposited on the AL453 steel by means of the screen printing method using a paste composed of fine powder prepared via EDTA gel processes. The post-oxidation phase, chemical composition, and morphology of the coating were investigated, with particular focus on the coating/metal substrate interface. Finally, the performance of the investigated metal/ceramic composite was evaluated in terms of $\mathrm{Cr}$ vaporization rate and contact area specific resistance using an interconnect-cathode interface setup in the
AL453/MC/LSCM/LSF/LSCM/MC/AL453 and AL453/ LSCM/LSF/LSCM/AL453 systems.

\section{Experimental}

Preparation of steel samples

The material used for the experiments was the commercial AL453 ferritic steel from Allegheny Ludlum, Germany, with the chemical composition of: $\mathrm{Fe}$ (Bal.), $\mathrm{Cr}$ (22.0 mass\%), $\mathrm{Mn}$ (0.3 mass\%), Ce (0.1 mass\%), Ti (0.02 mass\%), Si $(0.08$ mass\%), $\mathrm{Al}(0.6$ mass $\%), \mathrm{P}(0.02$ mass $\%), \mathrm{S}$ (0.03 mass\%), and $\mathrm{C}(0.03$ mass $\%)$. Steel coupons in the form of rectangular plates with the dimensions $20 \times 10 \times 0.5 \mathrm{~mm}$ (for $\mathrm{Cr}$ vaporization tests) and $10 \times 10 \times 0.5 \mathrm{~mm}$ (for electrical resistance measurements) were cut from the supplied material. The surfaces of specimens were ground with 100 - to 1,000-grit $\mathrm{SiC}$ papers and then polished with a $0.3-\mu \mathrm{m}$ alumina slurry, ultrasonically degreased, and finally washed in acetone and ethanol immediately prior to use.

\section{Preparation of powders and screen printing pastes}

The syntheses of $\mathrm{Mn}_{1.5} \mathrm{Co}_{1.5} \mathrm{O}_{4}$ (MC), $\mathrm{La}_{0.8} \mathrm{Sr}_{0.2} \mathrm{FeO}_{3}$ (LSF), and $\mathrm{La}_{0.8} \mathrm{Sr}_{0.2} \mathrm{Co}_{0.5} \mathrm{Mn}_{0.5} \mathrm{O}_{3}$ (LSCM) were performed using the sol-gel method with EDTA as the complexing agent of metal cations in a water solution, also known as the EDTA gel processes [22]. Manganese(II) nitrate tetrahydrate $\mathrm{Mn}\left(\mathrm{NO}_{3}\right)_{2} \times 4 \mathrm{H}_{2} \mathrm{O}$ (SIGMA-ALDRICH, $\geq 97.0 \%$ ), cobalt (II) nitrate hexahydrate $\mathrm{Co}\left(\mathrm{NO}_{3}\right)_{2} \times 6 \mathrm{H}_{2} \mathrm{O}$ (SIGMAALDRICH, $99.999 \%$ trace metals basis), lanthanum(III) nitrate hexahydrate $\mathrm{La}\left(\mathrm{NO}_{3}\right)_{3} \times 6 \mathrm{H}_{2} \mathrm{O}$ (FLUKA, puriss. p.a., $\geq$ $99.0 \%$ ), strontium nitrate $\mathrm{Sr}\left(\mathrm{NO}_{3}\right)_{2}$ (SIGMA-ALDRICH, puriss., $\geq 98 \%$ ), and iron(III) nitrate nonahydrate $\mathrm{Fe}$ $\left(\mathrm{NO}_{3}\right)_{3} \times 9 \mathrm{H}_{2} \mathrm{O}$ (ALDRICH, $99.99 \%$ trace metals basis) were used as starting materials, and EDTA $\left(\mathrm{C}_{10} \mathrm{H}_{16} \mathrm{~N}_{2} \mathrm{O}_{8}\right.$, ALDRICH, $99.995 \%$ ) and an ammonium hydroxide solution ( $28 \% \mathrm{NH}_{3}$ in $\mathrm{H}_{2} \mathrm{O}$, SIGMA-ALDRICH, $99.99 \%$ trace metals basis) were used in as-received form as chelating agents. The salts with known dry matter content were used for the preparation of $1.0 \mathrm{M}\left(\mathrm{M}-\right.$ molar concentration $\left.m o l \mathrm{dm}^{-3}\right)$ $\mathrm{Mn}, \mathrm{Co}, \mathrm{La}, \mathrm{Sr}$, and Fe nitrate solutions, which were subsequently mixed in an appropriate ratio to yield the desired stoichiometry. To obtain gel precursors, the nitrate solutions were mixed with $0.1 \mathrm{M}$ EDTA solution, the volume of which was determined from the ratio 1 mol EDTA/ 1 mol metal cation. Constant $\mathrm{pH}=8$ was maintained via dropwise addition of ammonia. The aqueous solutions containing appropriate cation complexes were slowly heated and stirred at $363 \mathrm{~K}$ to evaporate the water until transparent glassy gels were obtained. The gels were then pyrolyzed at $873 \mathrm{~K}$ for $1 \mathrm{~h}$, crushed, and calcinated for $10 \mathrm{~h}$ in air at 1,073 K. After heat 
treatment, the powders were ground in a rotary-vibratory mill in dry ethanol for $5 \mathrm{~h}$ and finally dried at room temperature.

The resulting powders were fabricated into pastes. The pastes were prepared by mixing each of the $\mathrm{Mn}_{1.5} \mathrm{Co}_{1.5} \mathrm{O}_{4}$, $\mathrm{La}_{0.8} \mathrm{Sr}_{0.2} \mathrm{FeO}_{3}$ and $\mathrm{La}_{0.8} \mathrm{Sr}_{0.2} \mathrm{Co}_{0.5} \mathrm{Mn}_{0.5} \mathrm{O}_{3}$ powders in 5 wt.\% solution of ethyl cellulose (Fluka, pure powders) in terpineol anhydrous (ALDRICH, purum, mixture of isomers). The mixtures, which contained ca. 17 wt.\% of organic binder, were homogenized for $10 \mathrm{~h}$ using a three-roll mill.

\section{Coating process and oxidizing procedure}

To measure the contact area specific resistance, the setup shown in Fig. 1 was constructed. This setup, which had been proposed by Yang et al. [15], simulates the interconnectcathode structure in IT-SOFC stacks. The porous LSF thick films, representing the cathodes, were deposited on both sides of the approximately $1-\mathrm{mm}$ thick LSF substrate by screen printing the LSF paste and subsequent sintering at $1,423 \mathrm{~K}$ in air. To obtain the LSF substrates at $10 \mathrm{~mm}$ in diameter and thickness of ca. $1 \mathrm{~mm}$, the calcinated powders were isostatically pressed under $300 \mathrm{MPa}$ and afterwards sintered for $2 \mathrm{~h}$ in air at $1,623 \mathrm{~K}$. The LSF substrate with the porous screen-printed cathodes was then symmetrically "sandwiched" between two AL453 steel coupons representing interconnects (Fig. 1). In order to ensure electrical contact between the cathode and the interconnect, a conductive LSCM paste was applied; the conductivity of LSCM at $1,073 \mathrm{~K}$ is greater than that of $\mathrm{Mn}_{1.5} \mathrm{Co}_{1.5} \mathrm{O}_{4}\left(175 \mathrm{Scm}^{-1}\right.$ [18] vs. $90 \mathrm{Scm}^{-1}$ [23]).

In our studies, two types of steel interconnect - uncoated AL453 steel and steel coated with $\mathrm{Mn}_{1.5} \mathrm{Co}_{1.5} \mathrm{O}_{4}$-were applied. Prior to use, the uncoated polished steels were oxidized in air at $1,073 \mathrm{~K}$ for $48 \mathrm{~h}$. For the coated interconnects, the $\mathrm{Mn}_{1.5} \mathrm{Co}_{1.5} \mathrm{O}_{4}$ paste was deposited on the AL453 steel substrate using a 100-mesh screen and then dried at $353 \mathrm{~K}$ for $2 \mathrm{~h}$. Before the coating procedure, the steel coupons were abraded with 600 -grit $\mathrm{SiC}$ paper. The organic components were removed entirely from the paste by thermally annealing the coated specimens in air at $873 \mathrm{~K}$ for $30 \mathrm{~min}$. The oxidation of the coating was carried out in two stages. The first stage took place at $1,023 \mathrm{~K}$ for $12 \mathrm{~h}$ in the $\mathrm{Ar}-\mathrm{H}_{2}-\mathrm{H}_{2} \mathrm{O}$ gas mixture, with $p\left(\mathrm{H}_{2}\right) / p\left(\mathrm{H}_{2} \mathrm{O}\right)=94 / 6$ using an apparatus described previously [24]. In the second stage, the samples were oxidized in air at $1,073 \mathrm{~K}$ for $48 \mathrm{~h}$. The thickness of the deposited films was about 30-50 $\mu \mathrm{m}$. For morphological and chemical studies, some uncoated and coated specimens were thermally oxidized in air at $1,073 \mathrm{~K}$ for up to $100 \mathrm{~h}$.

Methods of sample characterization

The chemical composition of the powders was determined by means of atomic absorption spectroscopy (ASA) using the Pye Unicum SP90B spectrometer. The phase composition of the powders, bulk samples, and metal/ceramics composites was analyzed by means of the X'Pert XRD diffractometer (Panalytical) using $\mathrm{CuK}_{\alpha}$ radiation at a scan rate of $0.008^{\circ}$ per step. Qualitative phase analyses were carried out with the Rietveld method using HighScore Plus software (Panalytical) coupled with the X'Pert diffractometer and the standard data set PCPDFWIN v.2.3. Scanning electron microscopy (SEM; FEI Nova NanoSEM 200) coupled with an EDAX Genesis XM Xray microanalysis system was used to examine the morphology and chemical composition of the studied samples. Chromium vaporization rate tests of the uncoated and coated samples and of the sintered $\mathrm{Cr}_{2} \mathrm{O}_{3}$ bulk sample as a reference were performed in humidified air $\left(p\left(\mathrm{H}_{2} \mathrm{O}\right)=9.72 \times 10^{-2} \mathrm{~atm}\right)$ at $1,073 \mathrm{~K}$ for $55 \mathrm{~h}$. The details of the apparatus used for $\mathrm{Cr}$ vaporization rate tests and the preparation procedure of the air- $\mathrm{H}_{2} \mathrm{O}$ gas mixture have been described previously [25].

The electrical resistance of coated and uncoated steel in the interconnect-cathode interface setup (Fig. 1) was measured using the dc two-probe four-point technique with a constant current of $10 \mathrm{~mA}$. The apparatus and the methods used for measuring electrical resistance are described in [26]. The temperature dependence of resistivity was measured in air between 723 and $1,073 \mathrm{~K}$ with $25 \mathrm{~K}$ steps. The electrical resistance of an oxidized specimen is usually measured in terms of its area-specific resistance (ASR), which is defined as the product of resistance and nominal contact surface area of the oxide and steel. Due to the symmetrical design of the
Fig. 1 Test setup for the evaluation of contact ASR at the cathode-interconnect interface in the AL453/MC/ LSCM/LSF/LSCM/MC/AL453 system [15]

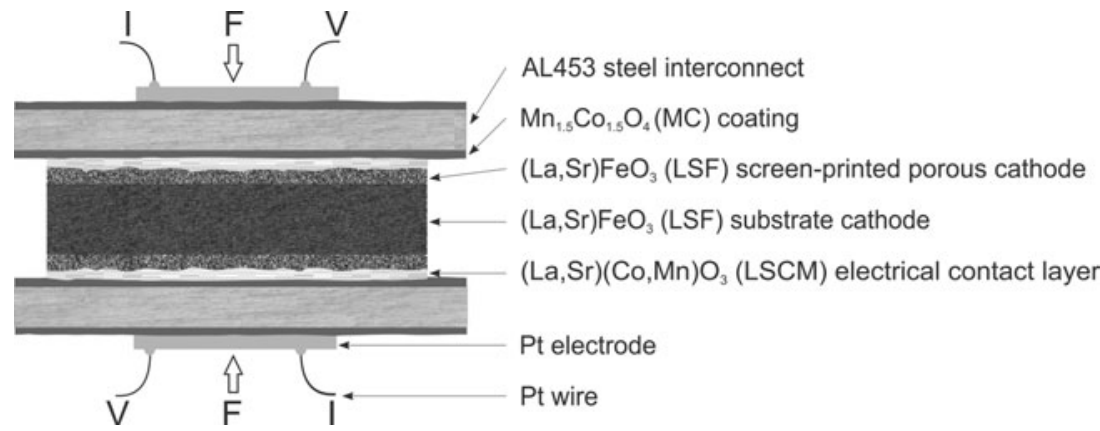


test, the area-specific resistance of the samples was calculated based on the obtained resistance values using the following formula:

$\mathrm{ASR}=\frac{\mathrm{R} \times \mathrm{A}}{2}$

where $R$ is electrical resistance $[\Omega]$ and $A$ is the surface area of the Pt layer $\left[\mathrm{cm}^{2}\right]$.

\section{Results and discussion}

$\mathrm{Mn}_{1.5} \mathrm{Co}_{1.5} \mathrm{O}_{4}$ spinel powder characteristics

Figure 2 shows an X-ray diffraction (XRD) pattern of the $\mathrm{Mn}_{1.5} \mathrm{Co}_{1.5} 0_{4}$ powder obtained using EDTA gel processes followed by calcination in air at $1,073 \mathrm{~K}$ for $10 \mathrm{~h}$. The X-ray phase analyses of the sample show that both the cubic $\mathrm{MnCo}_{2} \mathrm{O}_{4}$ and the tetragonal $\mathrm{Mn}_{2} \mathrm{CoO}_{4}$ phases form at room temperature. $\mathrm{MnCo}_{2} \mathrm{O}_{4}$ is a normal cubic spinel with $\mathrm{Mn}$ occupying octahedral interstitial sites and $\mathrm{Co}$ at both tetrahedral and octahedral interstitial sites in the face-centered cubic oxygen ion lattice, and $\mathrm{Mn}_{2} \mathrm{CoO}_{4}$ has an intermediate tetragonal spinel structure between the cubic $\mathrm{MnCo}_{2} \mathrm{O}_{4}$ and the tetragonal $\mathrm{Mn}_{3} \mathrm{O}_{4}[18,27,28]$. Since cobalt and manganese cannot be distinguished using X-rays, refinements were made with $50 \%$ of Co and $\mathrm{Mn}$ at each crystallographic site. Quantitative phase analyses showed that, after calcination in the afore-mentioned conditions, the $\mathrm{Mn}_{1.5} \mathrm{Co}_{1.5} \mathrm{O}_{4}$ powder consisted mostly of the tetragonal phase $-68 \pm 2 \%$, while the cubic phase constituted the remaining $32 \pm 2 \%$. This observation is consistent with an earlier work by Naka et al. [29] showing the co-existence of the cubic $\mathrm{Mn}_{1+\delta} \mathrm{Co}_{2-\delta} \mathrm{O}_{4}$ and tetragonal $\mathrm{Mn}_{2-\varepsilon} \mathrm{Co}_{1+\varepsilon} \mathrm{O}_{4}$ spinels. $\delta$ and $\varepsilon$ stand for deviation and are reported to be lower than 0.3 and 0.1 for the cubic and tetragonal spinels, respectively. Aukrust and Muan, who

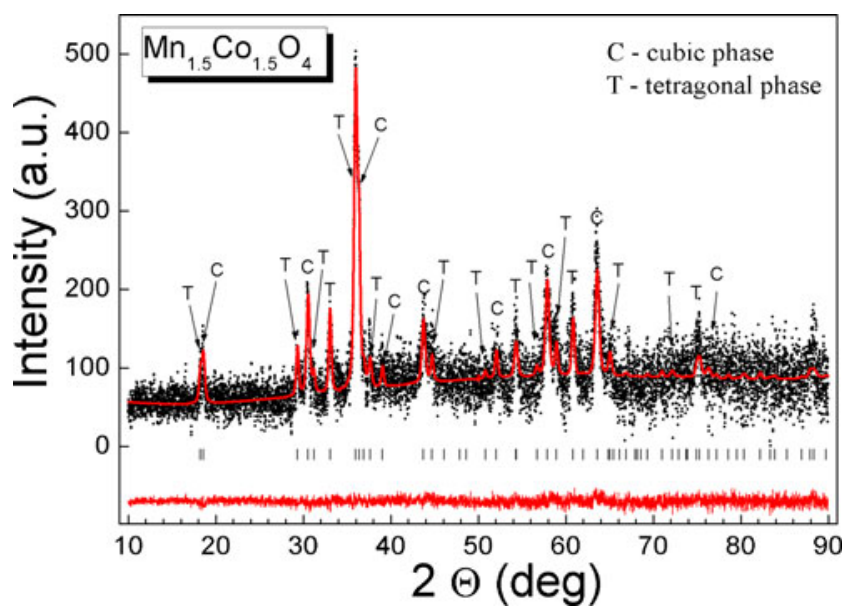

Fig. 2 X-ray diffraction pattern of the $\mathrm{Mn}_{1.5} \mathrm{Co}_{1.5} \mathrm{O}_{4}$ powder obtained via EDTA gel processes followed by calcination in air at $1,073 \mathrm{~K}$ for $10 \mathrm{~h}$ studied the phase diagram for the $\mathrm{Mn}_{3} \mathrm{O}_{4}$ and $\mathrm{Co}_{3} \mathrm{O}_{4}$ system in air, arrived at a similar conclusion [30].

The synthesized $\mathrm{Mn}_{1.5} \mathrm{Co}_{1.5} \mathrm{O}_{4}$ powder obtained via EDTA gel processes followed by calcination at optimal conditions exhibited high phase purity and was fine and agglomerated in nature due to the high surface energy of the particles. As can be seen in the SEM micrograph of the powder presented in Fig. 3, the particles of the powder are irregular in shape, with an average size of $0.2-1.0 \mu \mathrm{m}$.

Deviations from nominal stoichiometry $(\mathrm{Mn} / \mathrm{Co}=1.5: 1.5)$ of the prepared powder were analyzed by means of ASA. It was found that the examined powder had a molar ratio $\mathrm{Mn} /$ $\mathrm{Co}=1.50: 1.47$. In addition, the study of the sintering behavior and particle size distribution analysis of the samples, the results of which will be published elsewhere, proves that, using EDTA gel processes, it is possible to obtain very active $\mathrm{Mn}_{1.5} \mathrm{Co}_{1.5} \mathrm{O}_{4}$ spinel powders with the desired chemical composition and, due to short diffusion paths, good sinterability at lower temperatures. This is important for IT-SOFC application because the low fabrication temperature reduces the risk of crack formation during processing of the spinel-coated metallic substrate.

Characteristics of oxidation products of uncoated AL453 steel

Figure 4 presents SEM microphotographs of the surface of the oxide scale formed on the AL453 steel after $100 \mathrm{~h}$ of oxidation in air at $1,073 \mathrm{~K}$. The surface of this scale was composed of well-developed, thin $\mathrm{Cr}_{2} \mathrm{O}_{3}$ plates oriented in random directions and small amounts of $(\mathrm{Mn}, \mathrm{Cr})_{2} \mathrm{O}_{4}$ spinel precipitates formed on top of the chromia scale. The size of

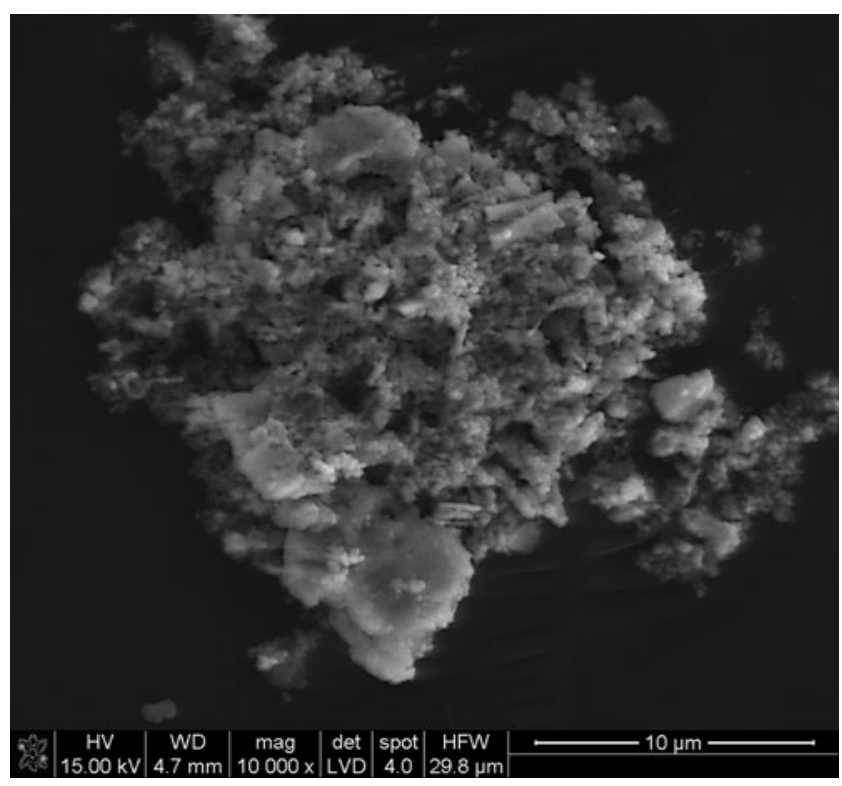

Fig. 3 SEM micrograph of the $\mathrm{Mn}_{1.5} \mathrm{Co}_{1.5} \mathrm{O}_{4}$ powder obtained via EDTA gel processes followed by calcination in air at $1,073 \mathrm{~K}$ for $10 \mathrm{~h}$ 
the above-mentioned plates was between 1 and $10 \mu \mathrm{m}$, while the thickness was equal to about $1 \mu \mathrm{m}$ (Fig. 4b). The phase and chemical compositions of the scale were confirmed via XRD and energy-dispersive spectroscopy (EDS) (Fig. 4) analyses.

Figure 5 shows the SEM microstructure of the oxide scale formed on the AL453 steel after oxidation in the above-mentioned conditions. The oxidation product was a single-layer scale with uniform thickness, consisting mainly of chromia doped with Fe. This was proved through EDS point analyses of the regions marked with symbols 1 and 2 (Fig. 5). The chromia scale had a thickness of about $3 \mu \mathrm{m}$ and exhibited good adhesion to the metal substrate.
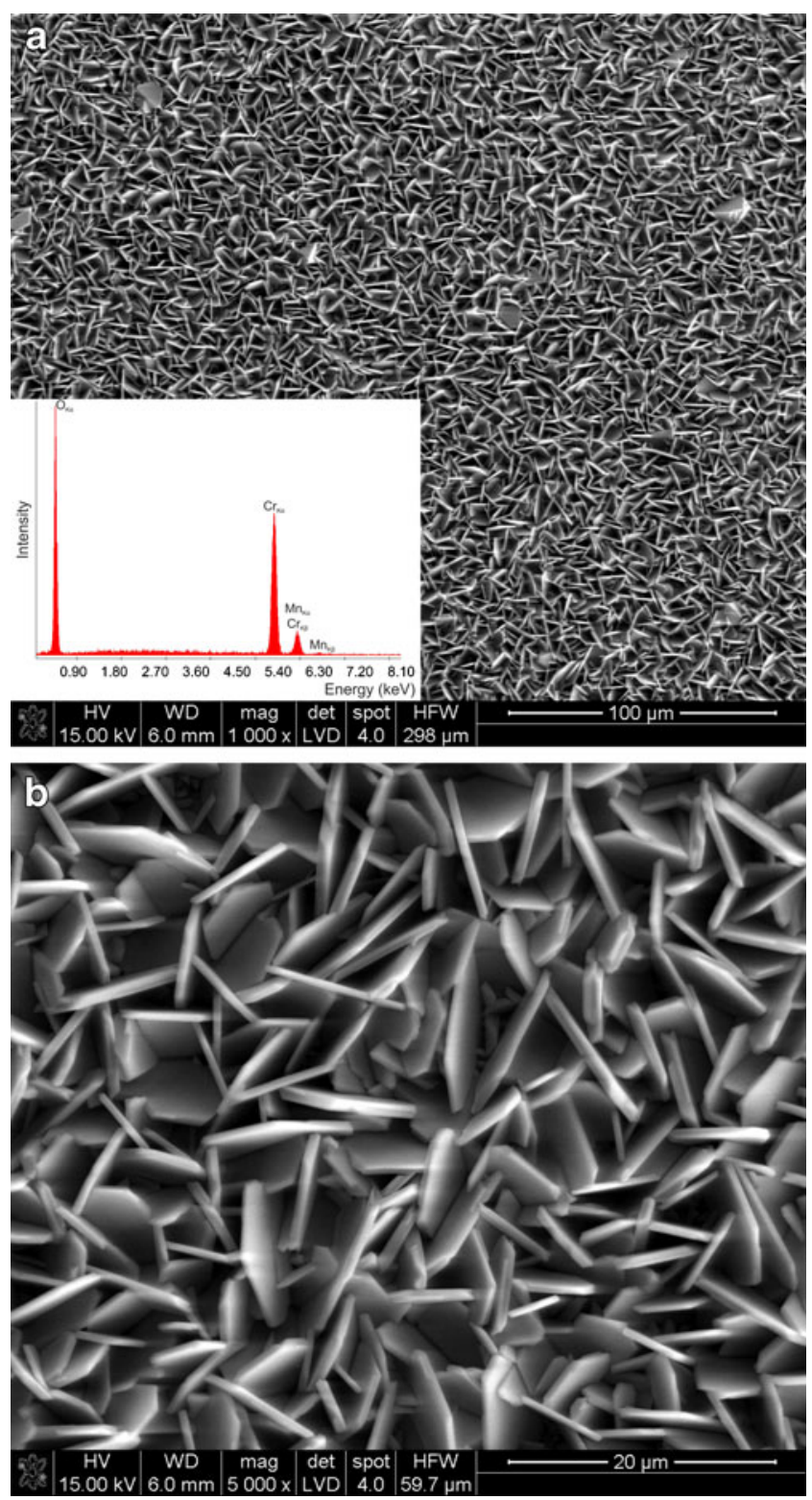

Fig. 4 SEM microphotographs of scale surfaces formed on the AL453 steel after $100 \mathrm{~h}$ of oxidation in air at $1,073 \mathrm{~K}$; magnification $\mathbf{a} \times 1,000$ and $\mathbf{b} \times 5,000$. Chromia content is marked in the lower left-hand corner of $\mathbf{a}$
Chemical analyses conducted at the steel/scale interface and within the metallic core revealed the presence of $\mathrm{SiO}_{2}$ (region 3-Fig. 5) and $\mathrm{Al}_{2} \mathrm{O}_{3}$ (region 4Fig. 5) precipitates. These oxides had formed as a result of internal oxidation of silicon and aluminum; the concentrations of these elements were higher than those found in region 5 (Fig. 5) corresponding to the steel. The presence of these precipitates beneath the scale improves its adhesion to the substrate [31] and hinders the diffusion of chromium into the scale, thereby significantly reducing the rate of chromia growth on the AL453 steel [32, 33].

Characteristics of the oxidation products of the AL453 steel coated with $\mathrm{Mn}_{1.5} \mathrm{Co}_{1.5} \mathrm{O}_{4}$

In order to obtain a dense $\mathrm{Mn}_{1.5} \mathrm{Co}_{1.5} \mathrm{O}_{4}$ coating that binds well to the ferritic steel, a two-stage heat treatment procedure was applied. This procedure included the initial annealing of the AL453/ $\mathrm{Mn}_{1.5} \mathrm{Co}_{1.5} \mathrm{O}_{4}$ composite layer in a reducing atmosphere $\left(\mathrm{Ar}-\mathrm{H}_{2}-\mathrm{H}_{2} \mathrm{O}\right.$ gas mixture) followed by re-synthesis in an oxygen-rich atmosphere (air). During $12 \mathrm{~h}$ of heat treatment in the $\mathrm{Ar}-\mathrm{H}_{2}-\mathrm{H}_{2} \mathrm{O}$ gas mixture at $1,073 \mathrm{~K}$, the coating was reduced into metallic Co and manganese oxide(II) as confirmed using XRD analysis (Fig. 6). Small amounts of $\mathrm{Co}_{3} \mathrm{O}_{4}$ and $\mathrm{Fe}_{2} \mathrm{O}_{3}$ phases were also detected in the reduced coating.

As a result of $48 \mathrm{~h}$ of re-synthesis of the $\mathrm{Mn}-\mathrm{Co}-\mathrm{O}$ coating in air at $1,073 \mathrm{~K}$, which proceeded according to the reaction given below [14]:

$4 \mathrm{Co}+2 \mathrm{MnO}+3 \mathrm{O}_{2} \rightleftarrows 2 \mathrm{MnCo}_{2} \mathrm{O}_{4}$

$2 \mathrm{Co}+4 \mathrm{MnO}+2 \mathrm{O}_{2} \rightleftarrows 2 \mathrm{Mn}_{2} \mathrm{CoO}_{4}$

A two-phase $\mathrm{Mn}_{1.5} \mathrm{Co}_{1.5} \mathrm{O}_{4}$ layer consisting of the $\mathrm{MnCo}_{2} \mathrm{O}_{4}$ and $\mathrm{Mn}_{2} \mathrm{CoO}_{4}$ spinels was obtained. This was confirmed by means of XRD analysis (Fig. 6). Furthermore, additional $\mathrm{Mn}_{1.5} \mathrm{Cr}_{1.5} \mathrm{O}_{4}$ and $\mathrm{CoMnCrO}_{4}$ spinel phases were found within the studied composite.

Detailed cross-sectional SEM-EDS investigations of the AL453 steel coated with the $\mathrm{Mn}_{1.5} \mathrm{Co}_{1.5} \mathrm{O}_{4}$ film after resynthesis revealed that the spinel coating adhered well to the steel substrate via an approximately 5 - $\mu \mathrm{m}$-thick continuous intermediate reaction layer composed mostly of $\mathrm{Mn}_{1.5} \mathrm{Cr}_{1.5} \mathrm{O}_{4}$ spinel phase with a cubic structure. This sublayer scale may also include some $\mathrm{CoMnCrO}_{4}$ precipitates. The presence of the $\mathrm{CoMnCrO}_{4}$ spinel was partially confirmed by means of X-ray analyses performed near the metal/layer interface, which was obtained by removing the outer oxide layer by successive grinding. A similar formation of the spinel phase had also been indicated in [34]. Figure 7a shows the SEM morphology of an 
Fig. 5 SEM microphotograph of the cross-section of the scale formed on the AL453 steel after $100 \mathrm{~h}$ of oxidation in air at $1,073 \mathrm{~K}$ and EDS point analyses spectra of the regions indicated in the microphotograph as $1,2,3,4$, and 5
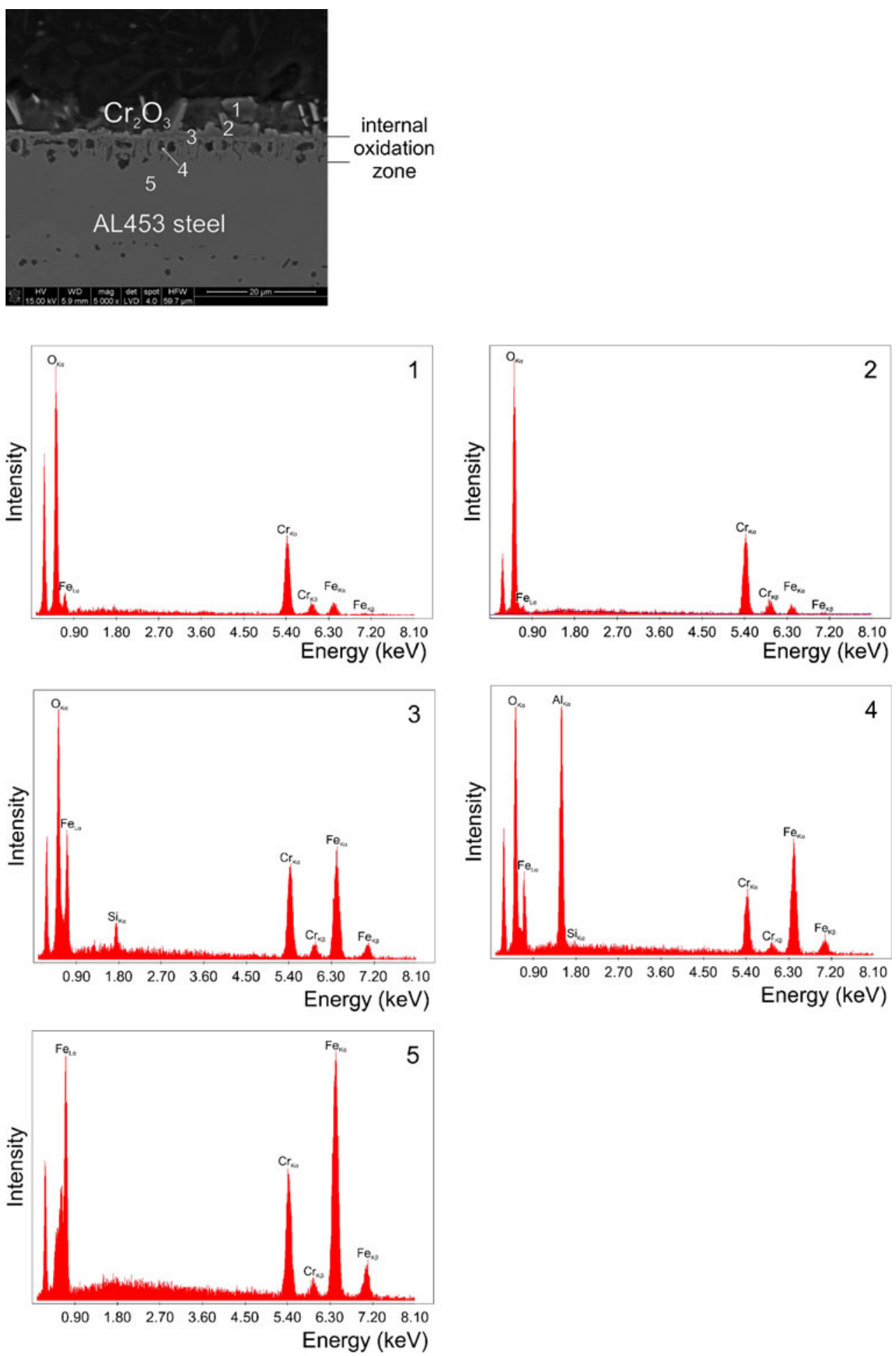

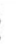




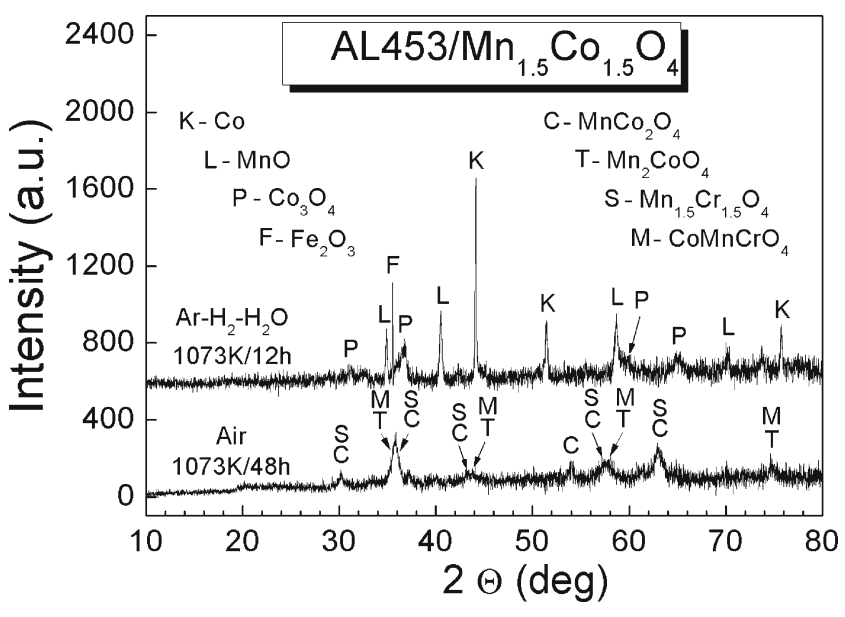

Fig. 6 X-ray diffraction pattern of AL453 steel with the Mn-Co-O coating after heat treatment in different conditions
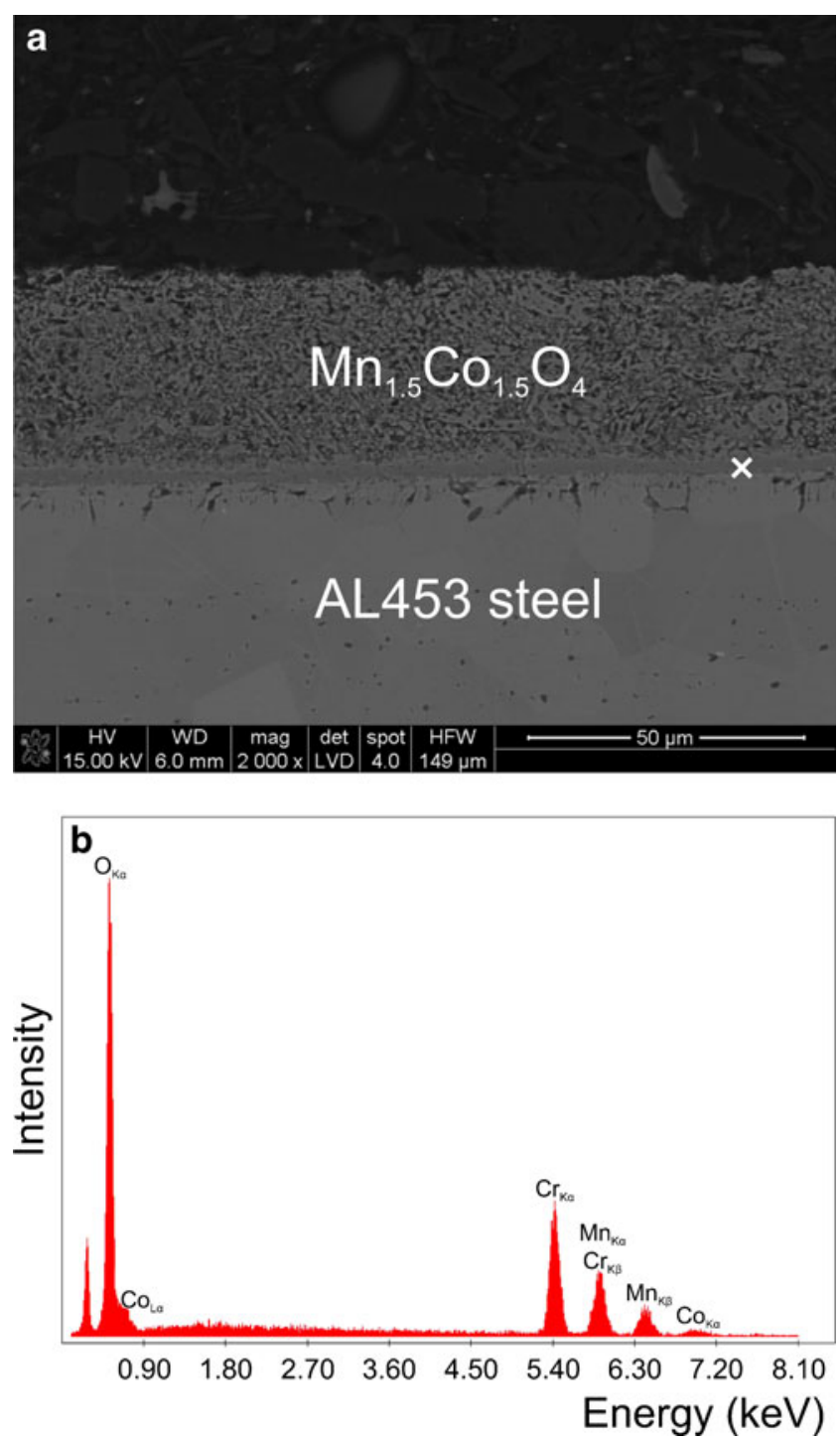

Fig. 7 a SEM microphotograph of the AL453 steel cross-section with the $\mathrm{Mn}_{1.5} \mathrm{Co}_{1.5} \mathrm{O}_{4}$ coating after $48 \mathrm{~h}$ of re-synthesis in air at $1,073 \mathrm{~K}$ and $\mathbf{b}$ EDS point analysis spectrum of point $x$ in $\mathbf{a}$ temperature, the highly electronically conductive $\mathrm{MnCo}_{2} \mathrm{O}_{4}$ phase with the cubic spinel structure was only identified in the $\mathrm{Mn}_{1.5} \mathrm{Co}_{1.5} \mathrm{O}_{4}$ coating material [35].

Cr vaporization tests of uncoated AL453 steel and steel coated with $\mathrm{Mn}_{1.5} \mathrm{Co}_{1.5} \mathrm{O}_{4}$ spinel

To evaluate the effectiveness of the applied coating, chromium vaporization rate tests of uncoated and coated AL453 ferritic steel were carried out in humid air, for $p\left(\mathrm{H}_{2} \mathrm{O}\right)=9.7 \times 10^{-2}$ atm, at a flow a rate of $2 \times 10^{-6} \mathrm{~m}^{3} \mathrm{~s}^{-1}$ and a temperature of $1,073 \mathrm{~K}$, for $55 \mathrm{~h}$, and under non-equilibrium conditions (unsaturated zone) [25]. Prior to each experiment, all samples were pre-oxidized in air at $1,073 \mathrm{~K}$ for $48 \mathrm{~h}$.

Figure 8 presents the chromium transport rate from the surface of uncoated AL453 steel and the steel coated with the $\mathrm{Mn}_{1.5} \mathrm{Co}_{1.5} \mathrm{O}_{4}$ compared against the results obtained in [21, 25, 36] with regard to the $\mathrm{Cr}$ vaporization rate of uncoated DIN 50049 steel and the exact same steel covered with three different types of material coatings- $(\mathrm{La}, \mathrm{Ca}) \mathrm{CrO}_{3},(\mathrm{La}, \mathrm{Sr}) \mathrm{CrO}_{3}$, and $(\mathrm{La}, \mathrm{Sr}) \mathrm{CoO}_{3}$ - and with the sintered $\mathrm{Cr}_{2} \mathrm{O}_{3}$ sample for reference [21].

For the AL453 ferritic steel, the loss of mass was nearly $50 \%$ smaller in comparison with the sintered $\mathrm{Cr}_{2} \mathrm{O}_{3}$ sample. This result is surprising considering the fact that the scale formed on this steel is built mainly of chromium oxide (Figs. 4 and 5) and has a highly developed surface. The decrease in the Cr vaporization rate observed for the uncoated steel is likely to be associated with less forceful evaporation of volatile chromium particles from the surface of the chromia scale due to their "entrapment" in the spaces formed by the randomly oriented $\mathrm{Cr}_{2} \mathrm{O}_{3}$ plates. The tests performed for the commercial DIN 50049 ferritic steel revealed a ca. $50 \%$ decrease in $\mathrm{Cr}$ vaporization rate compared to the reference sample (Fig. 8).

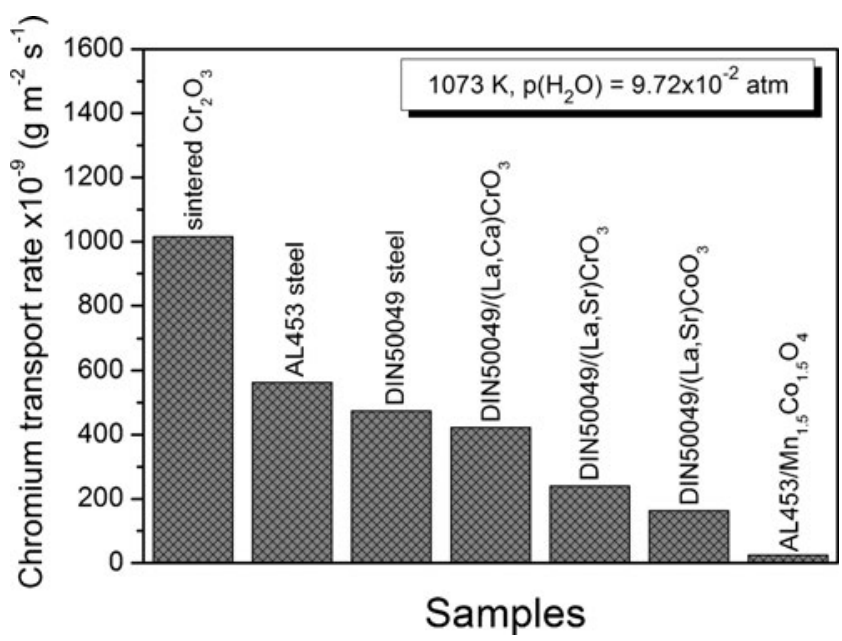

Fig. $8 \mathrm{Cr}$ vaporization rate from the surface of uncoated AL453 steel and from the steel with the $\mathrm{Mn}_{1.5} \mathrm{Co}_{1.5} \mathrm{O}_{4}$ coating in moist air at $1,073 \mathrm{~K}$ as compared to data from [21, 36] 
The considerable reduction in the vaporization rate was the result of the presence of a continuous, thin $\mathrm{Mn}_{1.5} \mathrm{Cr}_{1.5} \mathrm{O}_{4}$ spinel layer formed on the outer part of the chromia scale as indicated by morphological and chemical studies of the oxidized DIN 50049 steel [21].

Studies by Konycheva et al. [37] showed that the continuous layer of $\mathrm{MnCr}_{2} \mathrm{O}_{4}$ spinel formed on the outer part of the $\mathrm{Cr}_{2} \mathrm{O}_{3}$ scale after oxidation of Crofer 22 APU steel at $1,073 \mathrm{~K}$ reduces the $\mathrm{Cr}$ vaporization rate by over three times with respect to the ODS $\left(\mathrm{Cr} 5 \mathrm{Fe}+\mathrm{Y}_{2} \mathrm{O}_{3}\right)$ alloy; in the same heat treatment conditions, only $\mathrm{Cr}_{2} \mathrm{O}_{3}$ is formed on the latter alloy. Since chromia activity in $\mathrm{Mn}_{1.5} \mathrm{Cr}_{1.5} \mathrm{O}_{4}$ decreases to a level below 1 , then according to the equation [37]:

In $\mathrm{p}_{\mathrm{CrO}_{2}(\mathrm{OH})_{2}}=-\frac{\Delta_{\mathrm{r}(5)} \mathrm{H}^{\mathrm{o}}}{2 \mathrm{R}}\left(\frac{1}{\mathrm{~T}}\right)+\mathrm{C}^{\prime}+\mathrm{In} \mathrm{a}_{\mathrm{Cr}_{2} \mathrm{O}_{3}}$

where $a_{\mathrm{Cr}_{2} \mathrm{O}_{3}}$ is the activity of chromium oxide, $C^{\prime}$ is the constant, and $\Delta_{\mathrm{r}(5)} H^{\circ}$ is the standard change in the enthalpy of the following reaction:

$\mathrm{Cr}_{2} \mathrm{O}_{3}+\frac{3}{2} \mathrm{O}_{2(\mathrm{~g})}+2 \mathrm{H}_{2} \mathrm{O}_{(\mathrm{g})} \rightleftarrows 2 \mathrm{CrO}_{2}(\mathrm{OH})_{2(\mathrm{~g})}$

the partial vapor pressure of volatile $\mathrm{CrO}_{2}(\mathrm{OH})_{2}$, a major component of volatile chromium compounds, is also reduced. The formation of a spinel layer on ferritic steels thus leads to an expected decrease in the vaporization rate of chromium.

It follows from Fig. 8 that the application of protective coatings on the studied ferritic steels makes it possible to reduce chromium emissions more efficiently in comparison to the uncoated steel. The lowest $\mathrm{Cr}$ vaporization rate, lower by a factor of almost 23 than the $\mathrm{Cr}$ vaporization rate observed for uncoated AL453 steel, was found in the case of the $\mathrm{Mn}_{1.5} \mathrm{Co}_{1.5} \mathrm{O}_{4}$ film. The application of $(\mathrm{La}, \mathrm{Sr}) \mathrm{CoO}_{3}$, ( $\mathrm{La}, \mathrm{Sr}) \mathrm{CrO}_{3}$, or $(\mathrm{La}, \mathrm{Ca}) \mathrm{CrO}_{3}$ coatings can also suppress $\mathrm{Cr}$ vaporization, but not as effectively.

In the studied composite layers, the reaction between the chromium originating from the steel and the coating component may occur at the coating/steel interface. Figure 9 shows the SEM micrograph of the polished cross-section of the AL453/ $\mathrm{Mn}_{1.5} \mathrm{Co}_{1.5} \mathrm{O}_{4}$ composite layer and an EDS line scan across the multilayer metal/oxide interface between the film and the steel substrate after $55 \mathrm{~h}$ of oxidation in humid air at $1,073 \mathrm{~K}$ and for $p\left(\mathrm{H}_{2} \mathrm{O}\right)=9.7 \times 10^{-2} \mathrm{~atm}$.

The SEM-EDS study combined with XRD analysis showed that the $\mathrm{Mn}_{1.5} \mathrm{Co}_{1.5} \mathrm{O}_{4}$ film with its moderate porosity exhibited good adhesion to the continuous intermediate reaction layer that had developed between the film and the metallic core and was composed of the $\mathrm{Mn}_{1.5} \mathrm{Cr}_{1.5} \mathrm{O}_{4}$ spinel due to the diffusion of chromium from the steel to the substrate/film interface. From Fig. 9b showing the EDS line runs for $\mathrm{Cr}, \mathrm{Fe}, \mathrm{Co}, \mathrm{Mn}, \mathrm{Si}$ and $\mathrm{O}$, performed along the white line of the boundary region, it can be seen that the intermediate layer was enriched with $\mathrm{Mn}, \mathrm{Cr}$, and $\mathrm{O}$. In the outer portion of the applied coating, the
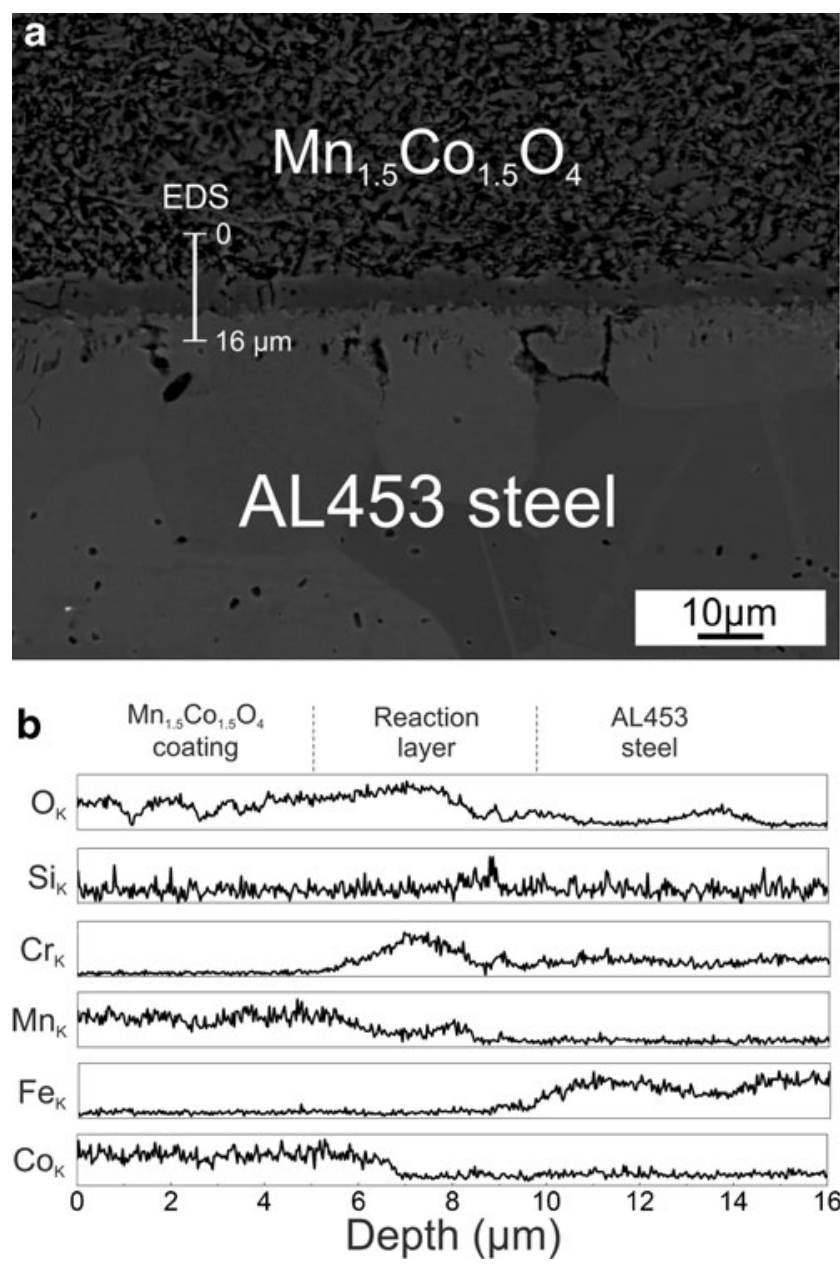

Fig. 9 Microstructure of the AL453/ $\mathrm{Mn}_{1.5} \mathrm{Co}_{1.5} \mathrm{O}_{4}$ composite layer cross-section after $55 \mathrm{~h}$ of oxidation in moist air at 1,073 K: a SEM microphotograph of the polished cross-section and $\mathbf{b}$ EDS line analysis (along the line in a

distribution of $\mathrm{Mn}, \mathrm{Co}$, and $\mathrm{O}$ was uniform, and their concentration corresponded to the stoichiometry of $\mathrm{Mn}_{1.5} \mathrm{Co}_{1.5} \mathrm{O}_{4}$ as confirmed by means of semiquantitative elemental EDS analysis. Furthermore, the increased $\mathrm{Cr}, \mathrm{Si}$, and $\mathrm{O}$ content at the metal/scale interface (Fig. 9b) may suggest the presence of $\mathrm{SiO}_{2}$ and $\mathrm{Cr}_{2} \mathrm{O}_{3}$ precipitates in the internal oxidation zone. It is important to note that the EDS line scan profile indicated a decrease in the content of chromium after the formation of the intermediate reaction layer (Fig. 9b). Thus, the $\mathrm{Mn}_{1.5} \mathrm{Co}_{1.5} \mathrm{O}_{4}$ coating made it possible to limit the emission of volatile chromium compounds to the cathode space of the IT-SOFC as confirmed by $\mathrm{Cr}$ vaporization tests (Fig. 8). A similar effect of the $(\mathrm{Mn}, \mathrm{Co})_{3} \mathrm{O}_{4}$ spinel coating was observed in studies by other authors [38, 39].

Based on the data presented in Fig. 8, attempts were made to estimate the amounts of chromium that can be released in the cathode space as a result of transport of $\mathrm{CrO}_{2}(\mathrm{OH})_{2}$ volatile species from the surface of the oxidized uncoated AL453 steel and the steel coated with the 
$\mathrm{Mn}_{1.5} \mathrm{Co}_{1.5} \mathrm{O}_{4}$ thick film. In planar-type IT-SOFC stacks with interconnect-supported fuel cells, interconnects that provide a counter-current flow of gas are usually applied. A part of this cell element is shown in Fig. 10. The interconnect is shaped in the form of parallel channels, placed at $1.5 \mathrm{~mm}$ from one another. The cross-sectional area of the channel is $1.5 \times 1.5 \mathrm{~mm}$. Because the protruding part of the interconnect is in direct contact with the electrical contact layer, the other three walls of the channel are potentially susceptible to the effect of $\mathrm{Cr}$ vaporization.

Assuming a laminar flow of air with a humidity of $60 \%$ $\left(p\left(\mathrm{H}_{2} \mathrm{O}\right)=1.88 \times 10^{-2} \mathrm{~atm}\right)$ in the channel, the deposition of chromium on the cathode surface should occur at a rate of $1.1 \times 10^{-7} \mathrm{~g} \mathrm{~m}^{-2} \mathrm{~s}^{-1}$. This means that in the very short time of less than $33 \mathrm{~min}$, a monolayer of $\mathrm{Cr}$ containing $10^{18}$ atoms per $1 \mathrm{~m}^{2}$ will form over the entire surface of the cathode situated opposite the interconnects. Similar calculations for the $\mathrm{Al} 453 / \mathrm{Mn}_{1.5} \mathrm{Co}_{1.5} \mathrm{O}_{4}$ composite layer indicate that the formation of the afore-mentioned $\mathrm{Cr}$ monolayers will be delayed by up to $12 \mathrm{~h}$. It is therefore reasonable to modify the surface of the AL453 steel by applying appropriate protective coatings, which may play an important role as a barrier against the emission of the volatile chromium species. This issue is of fundamental importance for the proper operation of IT-SOFCs.

Contact ASR of uncoated AL453 steel and steel coated with $\mathrm{Mn}_{1.5} \mathrm{Co}_{1.5} \mathrm{O}_{4}$ spinel

To determine the electrical properties of the AL453/ $\mathrm{Mn}_{1.5} \mathrm{Co}_{1.5} \mathrm{O}_{4}$ composite layer and evaluate the usefulness of the elaborated procedure of its fabrication, the interconnects' contact ASR was measured using an interconnectcathode interface setup in the AL453/MC/LSCM/LSF/ LSCM/MC/AL453 and AL453/LSCM/LSF/LSCM/AL453 systems.

Figure 11 shows graphs illustrating the temperature dependence of contact ASR values calculated from Eq. (1) for resistance $(R)$ values measured in air for the uncoated AL453 steel and the steel coated with $\mathrm{Mn}_{1.5} \mathrm{Co}_{1.5} \mathrm{O}_{4}$. Prior to resistance measurements, the studied samples were oxidized for $100 \mathrm{~h}$ in air at $1,073 \mathrm{~K}$. The ASR values obtained for the investigated samples during the heating and cooling stages were similar, and that is why only the measurements

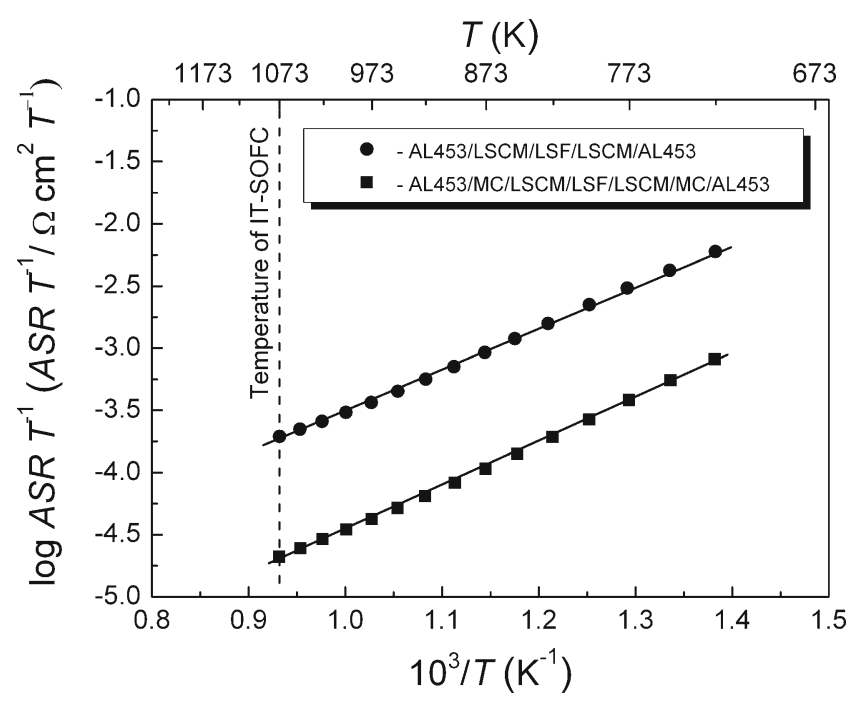

Fig. 11 Temperature dependence of contact ASR for uncoated AL453 steel in the AL453/LSCM/LSF/LSCM/AL453 system and steel coated with $\mathrm{Mn}_{1.5} \mathrm{Co}_{1.5} \mathrm{O}_{4}$ in the AL453/MC/LSCM/LSF/LSCM/MC/AL453 system

for the cooling stage were included in Fig. 11. The resistance of the studied samples measured in the range from 723 to $1,073 \mathrm{~K}$ decreased with temperature, which resembles a semiconductor-like behavior. The plots are nearly linear, which indicates thermally activated conductivity and suggests that the movement of small polarons via the transport of holes (or vacancies) is the predominant mechanism of electrical conduction [39].

The activation energy of conductivity was calculated from the slope of $\log (\mathrm{ASR} / T)$ vs. 1/T plot (Fig. 11) for both the system composed of the uncoated AL453 steel and the system consisting of the AL453 steel coated with $\mathrm{Mn}_{1.5} \mathrm{Co}_{1.5} \mathrm{O}_{4}$. The error of activation energy determination does not exceed $0.01 \mathrm{eV}$. The obtained $E_{\mathrm{a}}$ values were similar and were equal to 0.67 and $0.70 \mathrm{eV}$, respectively. This suggests the same mechanisms of electrical conduction in the studied samples. At the temperature of $1,073 \mathrm{~K}$, the oxidized AL453 steel coated with the $\mathrm{Mn}_{1.5} \mathrm{Co}_{1.5} \mathrm{O}_{4}$ spinel exhibits a contact ASR of about $0.02265 \pm 3 \times 10^{-5} \Omega \mathrm{cm}^{2}$, which is much lower than the contact ASR of the oxidized uncoated AL453 steel $\left(0.20875 \pm 3 \times 10^{-5} \Omega \mathrm{cm}^{2}\right)$. The ASR level of the AL453/ $\mathrm{Mn}_{1.5} \mathrm{Co}_{1.5} \mathrm{O}_{4}$ composite layer is well below the upper limit set for interconnect materials for SOFC application (ASR
Fig. 10 Schematic of the interconnect/cathode connection in an IT-SOFC stack

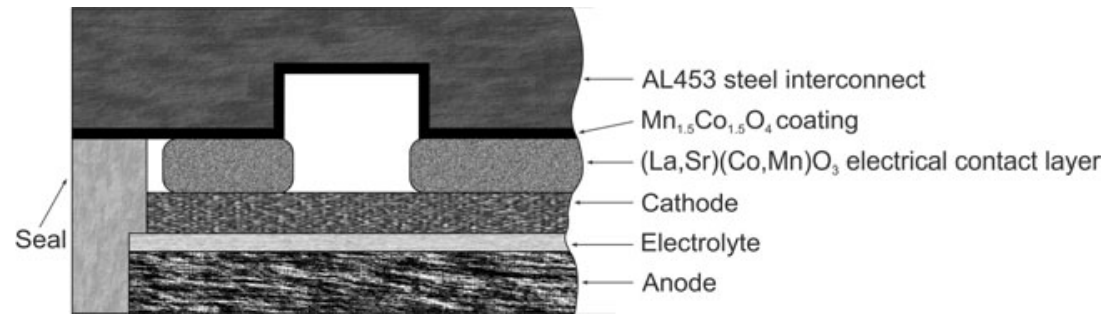


lower than $0.1 \Omega \mathrm{cm}^{2}$ ) [40]. The low contact ASR of the AL453/MC/LSCM/LSF/LSCM/MC/AL453 system in the $723-1,073 \mathrm{~K}$ range is comparable to the values reported by other researchers $[14,15,18]$. Its low value may mostly be attributed to the high electrical conductivity of the $\mathrm{Mn}_{1.5} \mathrm{Co}_{1.5} \mathrm{O}_{4}$ spinel [23] and to the crack-free, strongly adhesive protection layer formed on the steel substrate (Fig. 9).

The earlier discussion of the results shows the possibilities of application of the AL453 ferritic steel coated with the $\mathrm{Mn}_{1.5} \mathrm{Co}_{1.5} \mathrm{O}_{4}$ spinel in the construction of metallic interconnects operating in air atmospheres corresponding to the cathode space of IT-SOFC stacks.

\section{Conclusions}

EDTA gel processes proved to be a useful method for the synthesis of fine and homogeneous $\mathrm{Mn}_{1.5} \mathrm{Co}_{1.5} \mathrm{O}_{4}$ powders with the chemical and phase composition appropriate for use in pastes for screen printing. Using a two-stage heat treatment in the $\mathrm{Ar}-\mathrm{H}_{2}-\mathrm{H}_{2} \mathrm{O}$ gas mixture at $1,023 \mathrm{~K}$ and then in air at $1,073 \mathrm{~K}, \mathrm{Mn}_{1.5} \mathrm{Co}_{1.5} \mathrm{O}_{4}$ spinel coatings with good adhesion to the AL453 steel substrate were fabricated. Cr vaporization rate tests of the studied samples carried out for $55 \mathrm{~h}$ in the air- $\mathrm{H}_{2} \mathrm{O}$ gas mixture at $1,073 \mathrm{~K}$ showed an almost 23 -fold reduction for the AL453 steel coated with the $\mathrm{Mn}_{1.5} \mathrm{Co}_{1.5} \mathrm{O}_{4}$ compared to the uncoated steel. SEM-EDS investigations of the uncoated AL453 ferritic steel oxidized in air at 1,073 K show that the scale is built entirely of chromia. The morphology and chemical composition study of the $\mathrm{AL} 453 / \mathrm{Mn}_{1.5} \mathrm{Co}_{1.5} \mathrm{O}_{4}$ composite layer after its oxidation in air or air- $\mathrm{H}_{2} \mathrm{O}$ gas mixture at $1,073 \mathrm{~K}$ revealed the presence of an intermediate reaction layer composed of continuous $\mathrm{Mn}_{1.5} \mathrm{Cr}_{1.5} \mathrm{O}_{4}$ spinel at the steel/coating interface. EDS line scan analysis of chromium concentration in the $\mathrm{Mn}_{1.5} \mathrm{Co}_{1.5} \mathrm{O}_{4}$ coating indicated a significant decrease when moving away from the metallic core in the direction of the coating/gas interface. The results of these analyses in conjunction with the data from $\mathrm{Cr}$ vaporization rate tests indicate that the investigated film may effectively prevent chromium migration from steel interconnects into the cathode space of IT-SOFCs. The ASR of the AL453/ $\mathrm{Mn}_{1.5} \mathrm{Co}_{1.5} \mathrm{O}_{4}$ composite layer reaches a level of $0.02265 \pm$ $3 \times 10^{-5} \Omega \mathrm{cm}^{2}$ at $1,073 \mathrm{~K}$ in the AL453/MC/LSCM/LSF/ LSCM/MC/AL453 system; this level is significantly lower than the upper ASR limit for IT-SOFC interconnect materials and indicates that the $\mathrm{Mn}_{1.5} \mathrm{Co}_{1.5} \mathrm{O}_{4}$ coating lowers the electrical resistance at the cathode/interconnect interface.

Acknowledgments The authors would like to express their gratitude to Mrs. Barbara Trybalska from AGH University of Science and Technology, Faculty of Materials Science and Ceramics, Krakow, Poland, for her assistance in the SEM-EDS observations.
Open Access This article is distributed under the terms of the Creative Commons Attribution License which permits any use, distribution, and reproduction in any medium, provided the original author(s) and the source are credited.

\section{References}

1. Minh NQ, Takahashi T (1995) Science and technology of ceramic fuel cells. Elsevier, Amsterdam

2. Singhal SG, Kendall K (2003) High temperature solid oxide fuel cells, fundamentals, design and applications. Elsevier, Oxford

3. Fergus JW (2005) Metallic interconnects for solid oxide fuel cells. Mater Sci Eng A 397:271-283

4. Quadakkers WJ, Piron-Abellan J, Shemet V, Singheiser L (2003) Metallic interconnectors for solid oxide fuel cells - a review. Mater High Temp 20:115-127

5. Yang Z, Weil KS, Paxton DM, Stevenson JW (2003) Selection and evaluation of heat-resistant alloys for SOFC interconnect applications. J Electrochem Soc 150:A1188-A1201

6. Brylewski T, Nanko M, Maruyama T, Przybylski K (2001) Application of Fe-16Cr ferritic alloy to interconnector for a solid oxide fuel cell. Solid State Ionics 143:131-150

7. Fergus JW (2005) Sealants for solid oxide fuel cells. J Power Sources 147:46-57

8. Hilpert K, Das D, Miller M, Peck DH, Weiß R (1996) Chromium vapor species over solid oxide fuel cell interconnect materials and their potential for degradation processes. J Electrochem Soc 143:3642-3647

9. Kurokawa H, Jacobson CP, DeJonghe LC, Visco S (2007) Chromium vaporization of bare and of coated iron-chromium alloys at 1073 K. Solid State Ionics 178:287-296

10. Shong WJ, Liu CK, Chen CY, Peng CC, Tu HJ, Fey GTK, Lee RY, Kao HM (2011) Effects of lanthanum-based perovskite coatings on the formation of oxide scale for ferritic SOFC interconnect. Mater Chem Phys 127:45-50

11. Kadowaki T, Shiomitsu T, Madsuda E, Nakagawa H, Tsuneizumi H, Maruyama T (1993) Applicability of heat resisting alloys to the separator of planar type solid oxide fuel cell. Solid State Ionics 67:65-69

12. Yang ZG, Xia GG, Maupin GD, Stevenson JW (2006) Evaluation of perovskite overlay coatings on ferritic stainless steels for SOFC interconnect application. J Electrochem Soc 153:A1852-A1858

13. Chen X, Hou PY, Jacobson CP, Visco SJ, DeJonghe LC (2005) Protective coating on stainless steel interconnect for SOFCs: oxidation kinetics and electrical properties. Solid State Ionics $176: 425-433$

14. Yang Z, Xia G, Simner SP, Stevenson JW (2005) Thermal growth and performance of manganese cobaltite spinel protection layers on ferritic stainless steel SOFC interconnects. J Electrochem Soc 152:A1896-A1901

15. Yang Z, Xia G, Stevenson JW (2005) $\mathrm{Mn}_{1.5} \mathrm{Co}_{1.5} \mathrm{O}_{4}$ spinel protection layers on ferritic stainless steels for SOFC interconnect applications. Electrochem Solid-State Lett 8:A168-A170

16. Hua B, Pu J, Gong W, Zhang J, Lu F, Jian L (2008) Cyclic oxidation of Mn-Co spinel coated SUS 430 alloy in the cathodic atmosphere of solid oxide fuel cells. J Power Sources 185:419-422

17. Jue JF, Jusko J, Virkar AV (1992) Electrochemical vapor deposition of $\mathrm{CeO}_{2}$ : kinetics of deposition of a composite, two-layer electrolyte. J Electrochem Soc 139:2458-2465

18. Yang Z, Xia GG, Li XH, Stevenson JW (2007) $(\mathrm{Mn}, \mathrm{Co})_{3} \mathrm{O}_{4}$ spinel coatings on ferritic stainless steels for SOFC interconnect applications. Int J Hydrogen Energy 32:3648-3654 
19. Petric A, Ling H (2007) Electrical conductivity and thermal expansion of spinels at elevated temperatures. J Am Ceram Soc 90:1515-1520

20. Shaigan N, Qu W, Ivey DG, Chen W (2010) A review of recent progress in coatings, surface modifications and alloy developments for solid oxide fuel cell ferritic stainless steel interconnects. J Power Sources 195:1529-1542

21. Brylewski T, Dabek J, Przybylski K, Morgiel J, Rekas M (2012) Screen-printed ( $\mathrm{La}, \mathrm{Sr}) \mathrm{CrO}_{3}$ coatings on ferritic stainless steel interconnects for SOFCs using nanopowders prepared by means of ultrasonic spray pyrolysis. J Power Sources 208:86-95

22. Kakihana M (1996) Invited review "sol-gel" preparation of high temperature superconducting oxides. J Sol-Gel Sci Technol 6:7-55

23. Yang Z, Xia G, Nie Z, Templeton J, Stevenson JW (2008) Cemodified $(\mathrm{Mn}, \mathrm{Co})_{3} \mathrm{O}_{4}$ spinel coatings on ferritic stainless steels for SOFC interconnect applications. Electrochem Solid-State Lett 11: B140-B143

24. Przybylski K, Brylewski T, Prażuch J (2000) High temperature oxidation of $\mathrm{Fe}-\mathrm{Cr}$ steels with regard to their application as interconnectors for solid oxide fuel cells. Schriften des Forschungszentrums Jülich, Reihe Energietechnik/Energy Technology (Germany) 15(Part II):741-744

25. Brylewski T, Przybylski K (2008) Oxidation properties of coated $\mathrm{Fe}-25 \mathrm{Cr}$ steel with regard to the chromium vaporization effects under SOFC cathode operation conditions. Ann Chim Sci Matér 33:75-82

26. Chevalier S, Caboche G, Przybylski K, Brylewski T (2009) Effect of nano-layered coatings on the electrical conductivity of oxide scale grown on ferritic steels. J Appl Electrochem 39:529-534

27. Gautier JL, Cabezas C, Barbato S (1981) Reduction electrochimique de $\mathrm{MnCo}_{2} \mathrm{O}_{4}$ prepare a basse et haute temperature. Electrochim Acta 26:1377-1382

28. Restovic A, Rios E, Barbato S, Ortiz J, Gautier JL (2002) Oxygen reduction in alkaline medium at thin $\mathrm{Mn}_{\mathrm{x}} \mathrm{Co}_{3}-{ }_{\mathrm{x}} \mathrm{O}_{4}(0 \leq \mathrm{x} \leq 1)$ spinel films prepared by spray pyrolysis. J Electroanal Chem 522:141151

29. Naka S, Inagaki M, Tanaka T (1972) On the formation of solid solution in $\mathrm{Co}_{3}-{ }_{\mathrm{x}} \mathrm{Mn}_{\mathrm{x}} \mathrm{O}_{4}$ system. J Mater Sci 7:441-444
30. Aukrust E, Muan A (1963) Phase relations in the system cobalt oxide-manganese oxide in air. J Am Ceram Soc 46:511

31. Kofstad P (1988) High temperature corrosion. Elsevier, Essex

32. Atkinson A, Gardner JW (1981) The diffusion of $\mathrm{Fe}^{3+}$ in amorphous $\mathrm{SiO} 2$ and the protective properties of $\mathrm{SiO} 2$ layers. Corros Sci 21:49-58

33. Mikkelsen L, Linderoth S, Bilde-Sorensen JB (2004) The effect of silicon addition on the high temperature oxidation of a $\mathrm{Fe}-\mathrm{Cr}$ alloy. Mater Sci Forum 461-464:117-122

34. Wang K, Liu Y, Fergus JW (2011) Interactions between SOFC interconnect coating materials and chromia. J Am Ceram Soc 94:4490-4495

35. Bordeneuve H, Guillemet-Fritsch S, Rousset A, Schuurman S, Poulain V (2009) Structure and electrical properties of singlephase cobalt manganese oxide spinels $\mathrm{Mn}_{3}-{ }_{\mathrm{x}} \mathrm{Co}_{\mathrm{x}} \mathrm{O}_{4}$ sintered classically and by spark plasma sintering (SPS). J Solid State Chem 182:396-401

36. Przybylski K, Brylewski T (2011) Interface reactions between conductive ceramic layers and $\mathrm{Fe}-\mathrm{Cr}$ steel substrates in $\mathrm{SOFC}$ operating conditions. Mater Trans 52:345-351

37. Konycheva E, Penkalla H, Wessel E, Seeling U, Singheiser L, Hilpert K (2005) Comparison of chromium poisoning by the ODS alloy $\mathrm{Cr} 5 \mathrm{Fe} 1 \mathrm{Y} 2 \mathrm{O} 3$ and the high chromium ferritic steel Crofer 22APU. In: Singhal SC, Mizusaki J (eds) Solid oxide fuel cells IX (SOFC IX) -Electrochemistry Society Proceedings, PV 2005-07. The Electrochemical Society, Pennington, pp $1874-1878$

38. Gannon PE, Gorokhovsky VI, Deibert MC, Smith RJ, Kayani A, White PT, Sofie S, Yang Z, McCready D, Visco S, Jacobson C, Kurokawa H (2007) Enabling inexpensive metallic alloys as SOFC interconnects: an investigation into hybrid coating technologies to deposit nanocomposite functional coatings on ferritic stainless steels. Int J Hydrogen Energy 32:3672-3681

39. Verwey EJW (1951) Semiconducting materials. Butterworth Scientific, London

40. Zhu WZ, Deevi SC (2003) Opportunity of metallic interconnects for solid oxide fuel cells: a status on contact resistance. Mater Res Bull 38:957-972 